\title{
SEISMIC VULNERABILITY ASSESSMENT OF EXISTING RC MULTI- STORY BUILDINGS IN DUHOK CITY, KURDISTAN REGION OF IRAQ
}

\author{
AbDi Ismail ABdi and ABdulhameed ABdullah YASEen \\ Dept. of Civil Engineering, College of Engineering, University of Duhok, Kurdistan Region-Iraq
}

(Received: December 12, 2020; Accepted for Publication: February 14, 2021)

\begin{abstract}
The seismic vulnerability assessment of existing $\mathrm{RC}$ buildings is widely used in recent years. It has a vital role in the building rehabilitation and selection of retrofitting schemes. This study attempts to examine the seismic vulnerability of existing RC buildings in Duhok city to have understand and insight about their seismic performance under the effect of expected future earthquake events. For this purpose, six existing RC buildings have been selected with different number of stories to represent the building stock inventory in the city. ETABS V.18 software has been used for modeling and analysis of the buildings. The nonlinear static (pushover) analysis is employed for determining the load-deformation (pushover) curves. In addition, the improved capacity spectrum method of FEMA 440 is performed in the evaluation of the seismic performance of the buildings under the seismic hazard specified for the city. The outcomes of the study showed that most of the buildings have behaved like weak column-strong beams and vulnerable especially at ground stories. The buildings have overall limited structural damages with cracking damages in the columns at lower stories. Thus in all buildings, the strengthening for columns at ground stories is recommended.
\end{abstract}

KEYWORDS: Pushover Analysis, Nonlinear Static Analysis, Seismic Performance, RC Frame Buildings, CSM

\section{INTRODUCTION}

$\mathbf{K}$ urdistan Region (KR) is located on the northeast part of the Arabian plate which is the convergent region between Arabian and Eurasian plates. The collision between these two plates formed a boundary called Bitlis-Zagros Fold and Thrust Belt which is bounded the KR from north and northeast as shown in (Fig. 1.0). This belt is considered the most active region seismically among the surrounding seismic belts (Abdulnaby et al., 2014). Based on the probabilistic seismic hazard assessment and seismicity studies, conducted by (Alsinawi and Al-qasrani, 2003; Ameer et al., 2005; Hosseini et al., 2014; Wang et al., 2016; Said and Farman, 2018) for Iraq and Kurdistan Region for different time periods, medium to high earthquakes hit the region at shallow depth but the magnitude $(\mathrm{Mw})$ rarely exceeds $7.0,(\mathrm{Mw}$ is moment magnitude scale). This is clearly shown in the instrumental seismicity catalogue in (Fig. 2.0) provided by (Wang et al., 2016) of the period (1900 to 2009) for Iraq and surrounding regions. It consists of twenty thousand different magnitude earthquakes, about $90 \%$ of the events have shallow focal depth $(0-35) \mathrm{km}$. The seismic hazard in terms of peak ground acceleration
(PGA) of Duhok city is specified as (0.2-0.4)g for a $2 \%$ probability of exceedance in 50 years according to (Wang et al., 2016; Said and Farman, 2018) studies. Yaseen, Begg and Nanos (2014) have specified PGA for the zone in which Duhok city is located as $(0.25-0.4) \mathrm{g}$. The seismic hazard of the city in terms of response spectral acceleration parameters at $0.2 \mathrm{sec}(\mathrm{Ss})$ and at 1.0 $\sec \left(\mathrm{S}_{1}\right)$ are found as $0.6 \mathrm{~g}$ and $0.2 \mathrm{~g}$ respectively, for 2475 years return period (Wang et al., 2016; Said and Farman, 2018; Al-shijbi et al., 2019). In addition, the last update of the Iraqi seismic blog (Ministry of housing and construction, 2017) has provided the same values of $S s$ and $S_{1}$ for the city. Moreover, based on the site parameters investigation of ( $\mathrm{Sa}$ 'ad Al-Deen and Abdulrasool, 2017) for Iraq, the site soil of Duhok city has been classified as B (rock) and D (stiff soil).

Even though, KR practices low to moderate earthquakes as found in the literature. But it is nearby to countries where devastating earthquakes occurred in recent years such as Turkey, the 2011 van earthquake; Iran, the 2003 Bam earthquake, and the earthquake on 12 Nov. 2017 shaken the northern border region between Iraq and Iran (Zare et al., 2017). These earthquakes are caused to thousands of human fatalities and building collapse. Therefore, 
attention has been raised about the seismic vulnerability and safety level of the existing buildings in $\mathrm{KR}$ in general and Duhok city in particular. Rapid development and growth in population over the last decades in KR lead to an increase in the construction of multistory buildings. On the other hand, due to the lack of seismic design codes of buildings for the region until now and inadequate plans for quality assurance during construction. It is questionable that whether the RC buildings in Duhok will resist or suffer damages during moderate to high future earthquakes. This study attempts to answer this question by assessing the seismic performance of existing RC buildings in Duhok city.

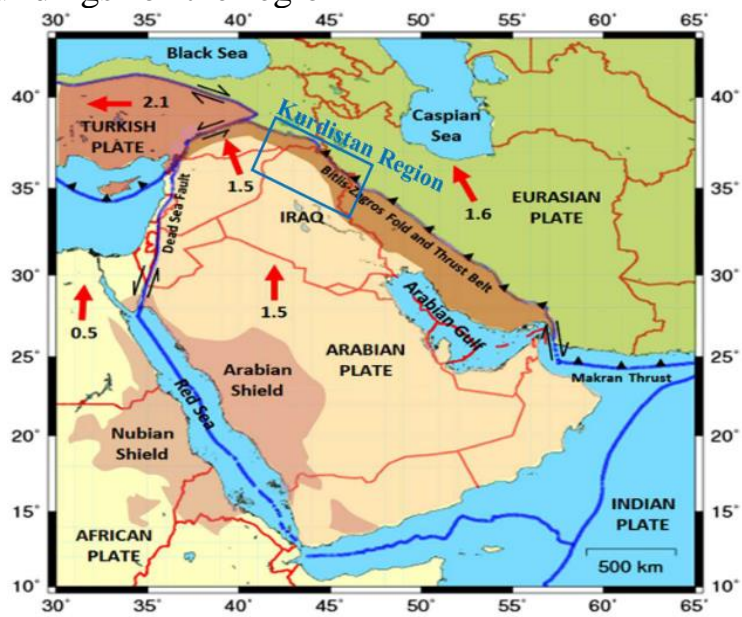

Fig. (1.0): Tectonic Setting of Iraq and surrounding regions (red arrows means plate motions in $\mathrm{cm} /$ year)

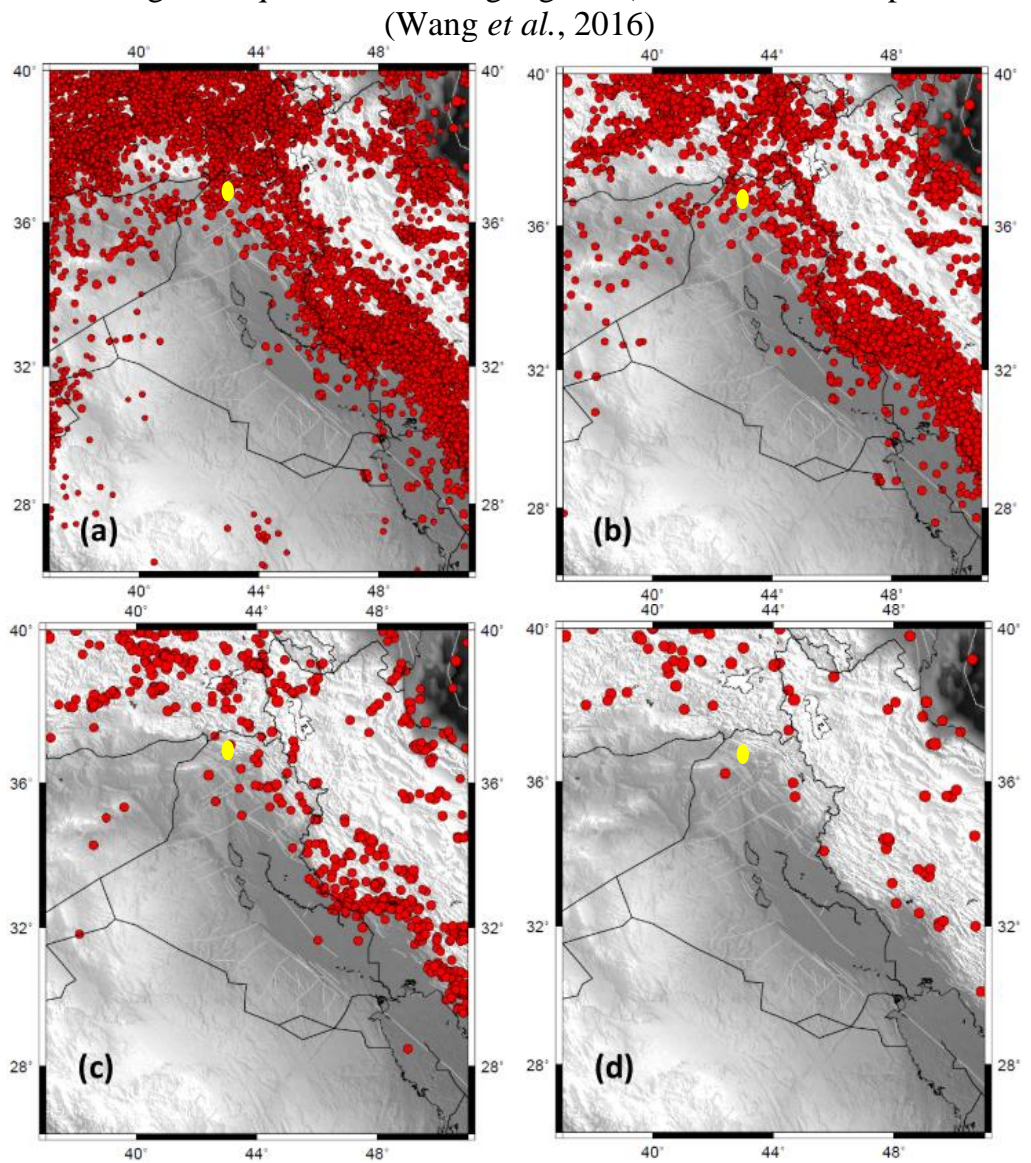

Fig. (2.0): Catalogue of Instrumental Seismicity in Iraq in terms of Mw. (a) $\mathrm{Mw}>3$, (b) $\mathrm{Mw}>4$, (c) $\mathrm{Mw}>5$, and (d) Mw > 6 (Wang et al., 2016) (Yellow point indicates Duhok city) 
Furthermore, throughout the seismic vulnerability assessment, the weak points of the building designs can be highlighted and proper recommendations can be provided, to improve the design of new buildings in order to reduce the collapse probability during future earthquakes. This way can increase urban safety and protect the community from the earthquake devastating effects. For seismic performance assessment, the realistic behavior of buildings during an earthquake is required which cannot be obtained by linear analysis methods. While, most of the structures experience inelastic behavior during strong earthquake ground motions (Elnashai and Di Sarno, 2015). Consequently, a non-linear analysis method has been considered in this study.

Generally, there are two main nonlinear analysis methods known as nonlinear static (Pushover) analysis and nonlinear dynamic (time history) analysis as given in Federal Emergency Management Agency (FEMA 356) document (ASCE, 2000). The time history analysis is the most accurate analysis method, but it is restricted due to its complexity, time-consuming, and its sensitivity to ground motion records. Thus it is recommended to be used for critical structures and for high-risk seismic zones (Pinho, 2007; Lagaros, Mitropoulou and Papadrakakis, 2014). In contrast, the ability of the nonlinear static analysis method in the evaluation of the seismic performance of structures and its simplicity compared to time history analysis nominated it as the most appropriate and popular analysis method. Especially, for buildings with low to a moderate height and where the effect of higher modes is not significant (Krawinkler, 1998; Aljassim and Husssain, 2018). FEMA 356 and (ATC 40, 1996) guidelines are considering different procedures based on pushover curve to evaluate the seismic performance of buildings for a given seismic action.

\section{RELATED WORKS}

Countless studies of this type have been conducted and published. However, none of them have considered the existing RC multistory buildings in Duhok city. This was another motivation of this study. Several similar works performed in Iraq and other countries by using nonlinear static analysis method and different software are pointed out as follows:

Al-jassim and Husssain (2018) have assessed the seismic vulnerability of existing $\mathrm{G}+5$ stories
$\mathrm{RC}$ building in Basra of Iraq. The building was modeled in SAP2000 software and pushover analysis was considered based on the CSM. The building was analyzed in three cases (regular, irregular in shape, and height) with the seismic coefficient of the city from the UBC97 code. Analysis outcomes showed that the building behaved strong column-weak beam mechanism and all plastic hinges performance were less than IO. It has indicated that building will be safe under the effect of earthquakes no greater than the designated one.

Ahmed (2013) has carried out a study about the seismic performance of a ten-story RC building subjected to seismic hazard of Mosul city of Iraq. The pushover analysis was carried out in the SAP2000 v.14 software. The analysis outcomes showed that the building was strong enough to resist the seismic load to a specific limit. The building behaved as a strong columnweak beam system. However, the formed hinges indicated the yielding in several beams. The author concluded that the analyzed building is safe for persons against earthquake forces.

Amer, Sobaih and Adel (2016) have investigated the seismic response of two groups of RC buildings designed per Iraqi building code requirements. The pushover analysis was carried out by using the capacity spectrum method to evaluate nonlinear responses for two seismic zones in Iraq. Baghdad and Duhok with three intensity hazard levels. Each group of the building consists of three, six, and nine-story RC buildings with soft-story building in the first group. The results showed that buildings designed by ISC will not fail under the earthquake in Iraq if constructed with a suitable design. Furthermore, the response outcomes from CSM of the ATC-55 version are higher than CSM of ATC-40. It was concluded that performance evaluation by Iraqi seismic code for maximum seismic hazard level and low intensity achieves reasonable results.

Abduljaleel, Taha and Yaseen (2020) have assessed the seismic vulnerability of existing RC buildings in Erbil city, the capital of KR of Iraq. In the study, three existing RC buildings of 6, 9, and 11 stories have been selected for the analysis. The buildings were modeled and analyzed in ETABS software by employing nonlinear static and incremental dynamic analysis. The results showed that the selected buildings are significantly vulnerable and poorly behaved under the expected earthquake of the city. Accordingly, seismic retrofitting and 
strengthening of the selected buildings were highly recommended.

\section{METHODOLOGY}

To achieve the objective of the study, obtaining the essential information related to building type, analytical method, and seismicity of the region is required.

\subsection{Classification of building types}

One of the most essential steps prior seismic vulnerability assessment studies is the data collection regarding to building stock inventory of the study area. Due to the lack of a statistic to indicate the total number of RC buildings in Duhok city with their number of stories. The street survey has been conducted in the first three months of 2019, for existing buildings based on the commercial streets plan with city center provided by the directorate of municipality of Duhok. The survey included data regarding the number of existing RC buildings, the number of stories within each building and their locations on the city map. The total number of buildings surveyed was 1804 buildings which included completed and those buildings which were in the finishing stages. The chart in (Fig. 3.0) depicts the surveyed buildings which are classified according to the number of stories. It is obvious from the chart that buildings of $\mathrm{G}+2$ and $\mathrm{G}+3$ ( $\mathrm{G}$ denotes to Ground story) categories occupy the major portion of the total surveyed building stock in the city. For facilitating data entry and specifying the location of buildings on the city map, ArcGIS 10.7 software has been used. The distribution of surveyed buildings is presented in (Fig. 3.0). The representative buildings for analysis have been selected according to this classification.

Hence, this number does not represent the exact number of existing RC buildings in the city. Because there were several buildings not located on those streets which were specified for the survey, and the city center survey was difficult due to the crowded buildings and daily life activities of people. Furthermore, it is important to mention that residential complexes were excluded from the survey.

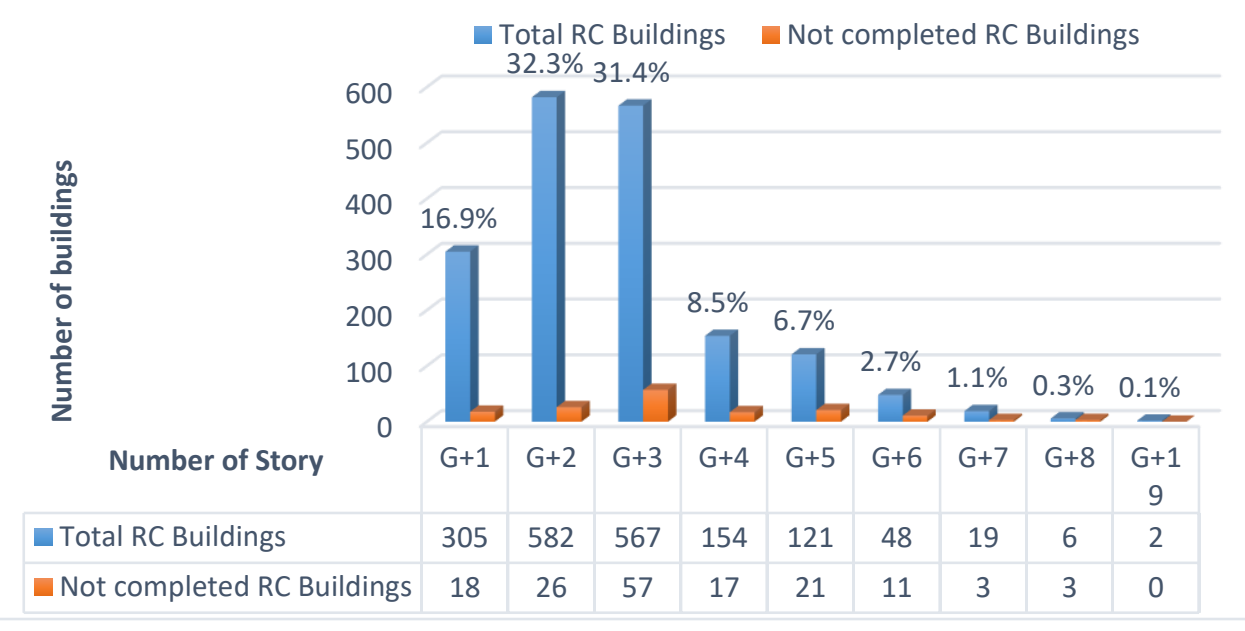




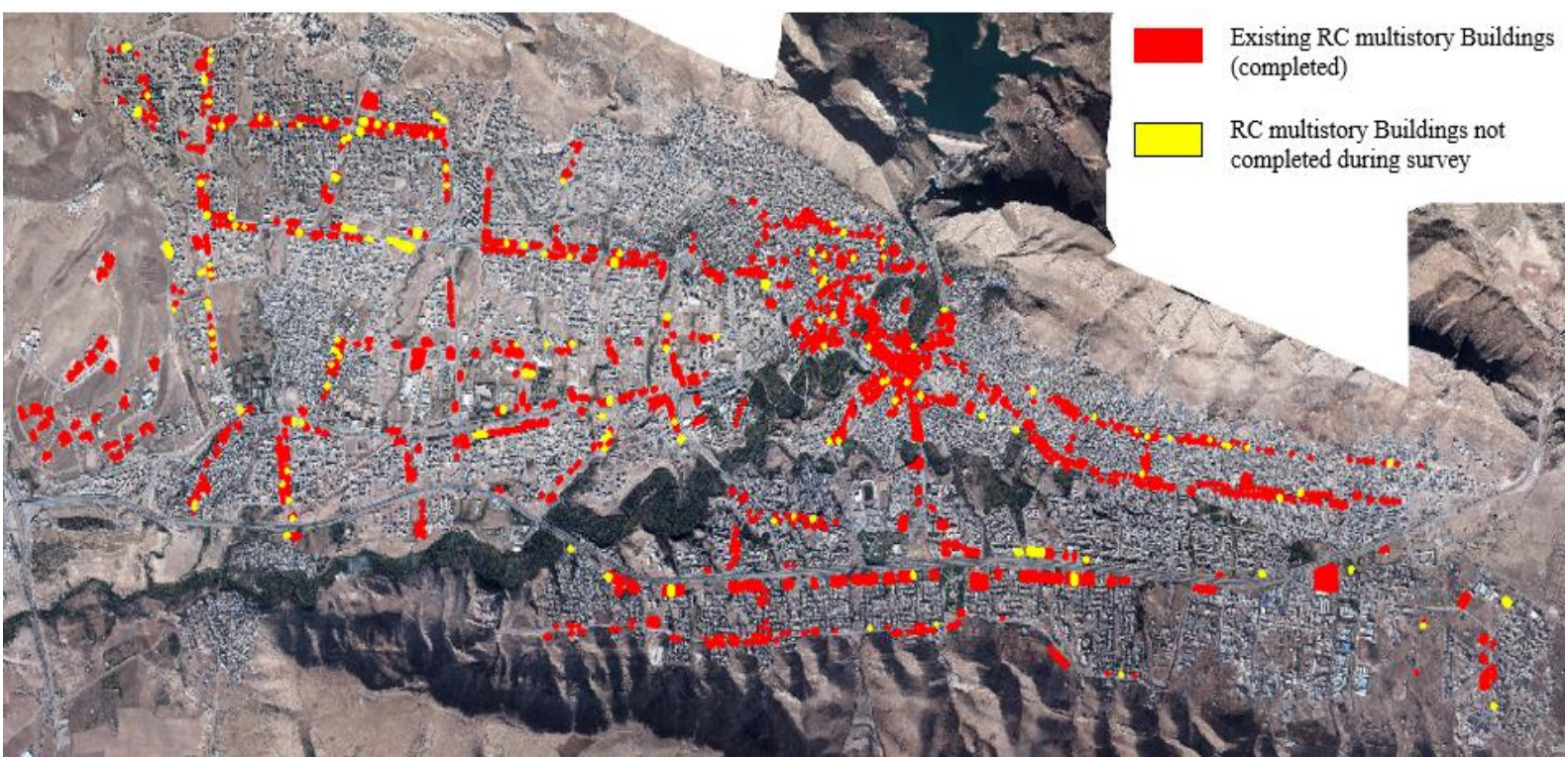

Fig. (3.0): (Top) Buildings classification based on number of stories, (bottom) Surveyed RC multi-story buildings distribution over Duhok city map

\subsection{Analytical method}

In this study, the pushover analysis was performed to evaluate the lateral capacity of buildings. It is the nonlinear static approximate method that evaluates the dynamic response of structure for a given earthquake by using static analysis. The pushover analysis practices the incremental iterative process in the solution of the static equilibrium equation of the structural model. The model subjected to constant gravity and monotonically increasing lateral loads of predefined pattern or displacement pattern. Several techniques available for lateral load application including; constant, adaptive, and multimodal load profile. In the conventional pushover analysis, the lateral load is assumed to remain constant during the analysis (ATC-55, 2005; Datta, 2010; Elnashai and Di Sarno, 2015).

The pushover analysis might be force control or displacement control. In the force control, the total lateral load applied on the structure in increments is known. In contrast, the displacement control applying the lateral displacement incrementally on the structure and similar to force control procedure changes the structural stiffness for each displacement increment. Usually, the pushover analysis performs to compute the total lateral load pushed the structure for the desired displacement. Consequently, the displacement control is more preferred (Datta, 2010) which has been applied in this study. The analysis result is expressed in a graphical representation called pushover curve (capacity curve), which represents the total base shear $(\mathrm{V})$ versus the total lateral displacement $(\delta)$ as shown in (Fig. 4.0, a). This curve is considered as a basis for the seismic performance evaluation of the structure (Elnashai and Di Sarno, 2015)

In this study, the improved capacity spectrum method (CSM) of FEMA-440 was carried out. For evaluating the seismic performance of existing buildings according to seismicity of the study area. The method has been introduced first in the 1970s as a rapid method for evaluating the seismic vulnerability of buildings by (freeman et al., 1975) as stated by (Freeman, 1998, 2004), then implemented by (ATC 40, 1996).

To perform the CSM, the first necessary step is the conversion of the capacity curve to capacity spectrum and 5\% damped elastic response spectrum to inelastic demand spectrum. Then, the converted curves are superimposed on a graph in acceleration-displacement response spectra (ADRS) format. The objective of CSM is to find the intersection point of both curves which is known as performance point (Chen and Lui, 2006) as presented in (Fig. 4.0, b). This point gives the maximum expected structural displacement result of specific earthquake demand. The determination of performance point requires a trial and error process which is described in detail in (ATC 40, 1996) document. Whereas, in this study, ETABS software has been used which automatically implements the procedure of CSM. The deformation demands estimated in the nonlinear analysis are required to be compared with the allowable limits presented in Table 1.0, for global performance assessment as provided in ATC-40. Nevertheless, the total drift of story i should not exceeds the term $0.33 \frac{V_{i}}{P_{i}}$ for structural stability (collapse prevention) 
checking (where; vi and pi are the shear force and total gravity load, respectively at story i). The local performance of a building is evaluated according to the plastic rotations that occurred in the components compared with the defined limits in the software.
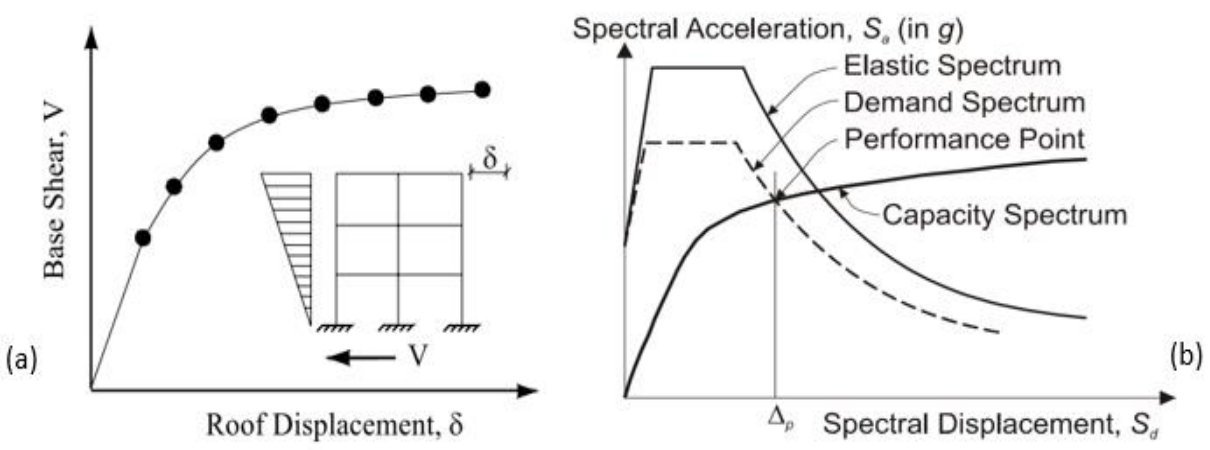

Fig. (4.0): (a) Pushover (capacity) curve of structure (Oguz, 2005), (b) Representation of capacity spectrum method (Boen and Tjhin, 2016)

Table (1.0): Deformation limits of performance levels (ATC 40, 1996)

\begin{tabular}{ccccc}
\hline \multicolumn{5}{c}{ Performance Level } \\
\hline Inter story drift limit & $\begin{array}{c}\text { Immediate } \\
\text { occupancy }\end{array}$ & Damage control & Life safety & Structural stability \\
\hline Maximum total drift & 0.01 & $0.01-0.02$ & 0.02 & $0.33 \frac{V_{i}}{P_{i}}$ \\
\hline Maximum inelastic drift & 0.005 & $0.005-0.015$ & No limit & No limit \\
\hline
\end{tabular}

\subsection{Case study description}

This study focused on the evaluation of the seismic performance of existing RC multistory buildings in Duhok, under the effect of seismic action specified for the city. For this purpose, six RC multistory buildings are selected to represent the surveyed building inventory of the city. The selected RC buildings are with a different number of stories in various places in the city. Different categories in the functional point of view are involved in the representative buildings. The buildings are designed and constructed by different consultant engineering bureaus which are most of them modern and have been built after 2010. The data has been collected in two stages; the first stage was obtaining design structural drawings, material properties, and designed gravity loads from the engineering bureaus. The second was field observation to make certain about the existence of buildings and their number of stories. Due to the lack of as-built drawings, in the site observation, the original drawings are verified with real existing buildings when possible. In the case of structural elements are covered with decorate materials or no permission was given by owners, the modeling of buildings was dependent on original drawings. One out of the selected buildings involved in this study is taken as the sample to describe in details in terms of its properties and structural detail here. Typical structural plan of building model 6 with reinforcement details of structural elements are shown in (Fig. 5.0). Table 3.0 to Table 5.0 are show other properties of the building, applied gravity loads and section properties of structural elements. Moreover, the structural plans of other building models are presented in (Fig. 6.0) and (Fig. 7.0) with their essential properties provided in Table 2.0. 
Table (2.0): Description of representative building models

\begin{tabular}{cccccccccccc}
\hline $\begin{array}{c}\text { Model } \\
\text { No. }\end{array}$ & Occupancy & $\begin{array}{c}\text { No. of } \\
\text { story }\end{array}$ & $\begin{array}{c}\text { Basem } \\
\text { ent } \\
\text { story } \\
\text { height }\end{array}$ & $\begin{array}{c}\text { Groun } \\
\text { d story } \\
\text { height }\end{array}$ & $\begin{array}{c}\text { Typical } \\
\text { story } \\
\text { height }\end{array}$ & $\begin{array}{c}\text { Concrete } \\
\text { grade of } \\
\text { vertical } \\
\text { elements }\end{array}$ & $\begin{array}{c}\text { Concrete } \\
\text { grade of } \\
\text { horizontal } \\
\text { elements }\end{array}$ & $\begin{array}{c}\text { Reinfor } \\
\text { cement } \\
\text { grade }\end{array}$ & $\begin{array}{c}\text { Live } \\
\text { load }\end{array}$ & $\begin{array}{c}\text { Super } \\
\text { dead } \\
\text { load }\end{array}$ \\
\hline 1 & Residential & $\mathrm{G}+3$ & ------ & 4.0 & 3.2 & 25 & 21 & 60 & 2.0 & 4.5 \\
\hline 2 & Residential & $\mathrm{G}+3$ & ------ & 4.2 & 3.2 & 30 & 25 & 60 & 2 & 3.5 \\
\hline 3 & Commercia & $\mathrm{B}+\mathrm{G}+4$ & 3.0 & 4.0 & 3.2 & 30 & 25 & 60 & 2.4 & 3.5 \\
\hline 4 & Residential & $\mathrm{B}+\mathrm{G}+4$ & 4.0 & 5.6 & 3.2 & 35 & 30 & 60 & 4.0 & 4.5 \\
\hline 5 & Residential & $\mathrm{B}+\mathrm{G}+5$ & 3.3 & 4.3 & 3.5 & 30 & 25 & 60 & 3.0 & 4.0 \\
\hline
\end{tabular}
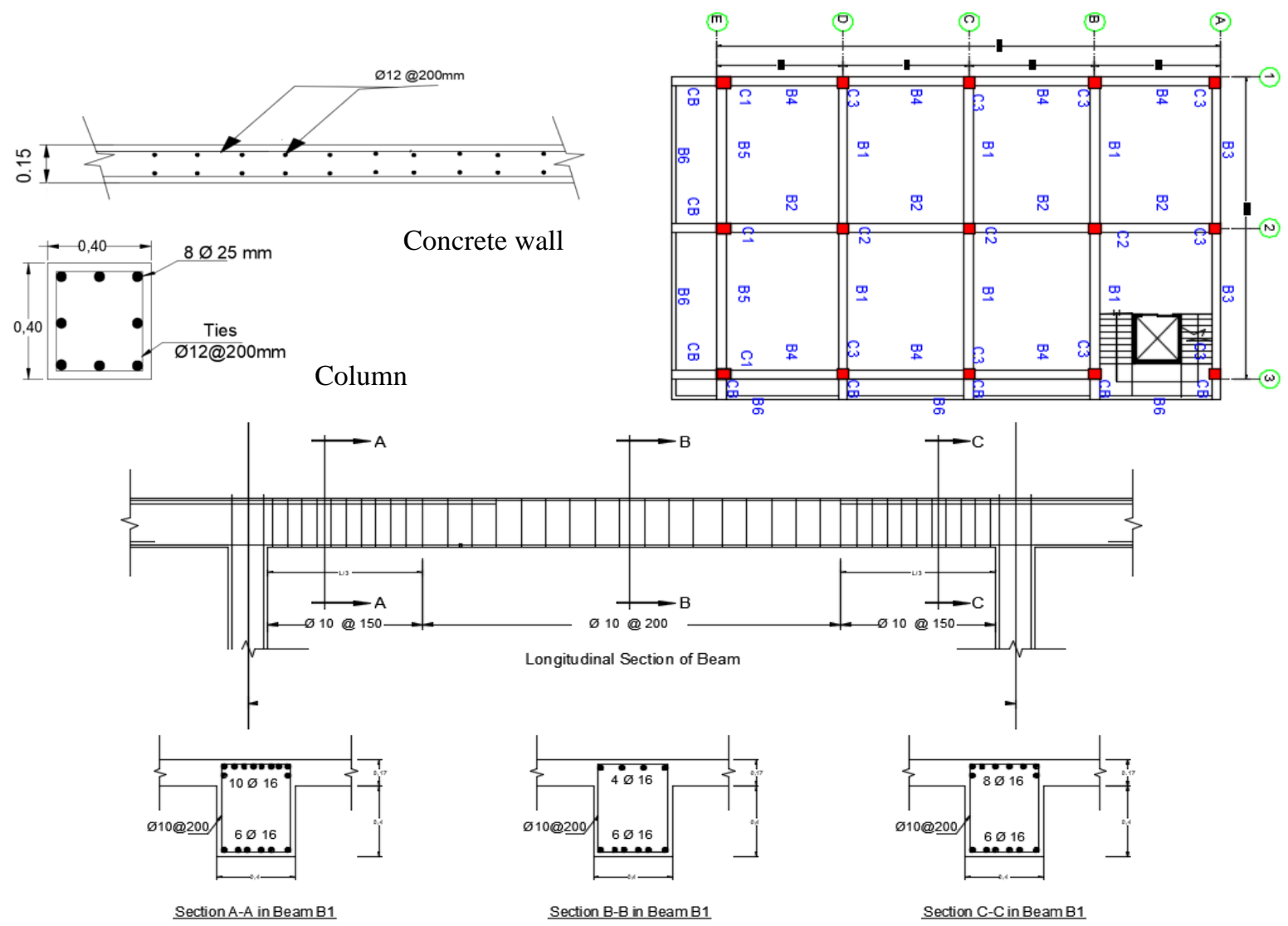

Fig. (5.0): Typical structural story plan and typical section details of shear walls, beam and columns of building model-6 
Table 3.0: General properties of RC building model- 06

\begin{tabular}{|c|c|}
\hline Content & Description \\
\hline Occupancy & Hotel \\
\hline No. of stories & $\mathrm{B}+\mathrm{G}+6$ \\
\hline Basement height & $3.7 \mathrm{~m}$ \\
\hline Ground story height & $4.5 \mathrm{~m}$ \\
\hline Typical story height & $3.4 \mathrm{~m}$ \\
\hline Slab thickness & $170 \mathrm{~mm}$ \\
\hline Infill wall material & $\begin{array}{c}\text { Ponza for interior and solid concrete } \\
\text { block for exteriors }\end{array}$ \\
\hline $\begin{array}{c}\text { Elevator and basement shear } \\
\text { wall thickness }\end{array}$ & $150 \& 300 \mathrm{~mm}$ \\
\hline Grade of concrete & $\begin{array}{c}30 \text { Mpa for columns and walls \& } 25 \\
\text { Mpa for beams and slab }\end{array}$ \\
\hline Grade of steel & Grade 60 \\
\hline Live load & $3.0 \mathrm{KN} / \mathrm{m}^{2}$ \\
\hline Supper dead load & $3.5 \mathrm{KN} / \mathrm{m}^{2}$ \\
\hline
\end{tabular}

Table (4.0): Section properties of RC beams of building Model-06

\begin{tabular}{|c|c|c|c|c|c|c|}
\hline Beams & $\begin{array}{c}\text { Dimension } \\
(\mathrm{mm})\end{array}$ & $\begin{array}{l}\text { Location } \\
\text { of Reinf. }\end{array}$ & End I & Middle & End J & Stirrups \\
\hline \multirow[t]{2}{*}{ B1 } & $400 \times 400$ & Top & $\begin{array}{c}10 \varnothing \\
16\end{array}$ & $4 \varnothing 16$ & $8 \varnothing 16$ & \multirow{14}{*}{$\begin{array}{c}\varnothing 12 @ \\
150 \& 200 \\
\mathrm{~mm}\end{array}$} \\
\hline & & Bottom & $6 \varnothing 16$ & $6 \varnothing 16$ & $6 \varnothing 16$ & \\
\hline \multirow[t]{2}{*}{ B2 } & $400 \times 400$ & Top & $5 \varnothing 16$ & $3 \varnothing 16$ & $5 \varnothing 16$ & \\
\hline & & Bottom & $5 \varnothing 16$ & $5 \varnothing 16$ & $5 \varnothing 16$ & \\
\hline \multirow[t]{2}{*}{ B3 } & $400 \times 400$ & Top & $5 \varnothing 16$ & $3 \varnothing 16$ & $5 \varnothing 16$ & \\
\hline & & Bottom & $4 \varnothing 16$ & $4 \varnothing 16$ & $4 \varnothing 16$ & \\
\hline \multirow[t]{2}{*}{ B4 } & $400 \times 400$ & Top & $4 \varnothing 16$ & $4 \varnothing 16$ & $4 \varnothing 16$ & \\
\hline & & Bottom & $4 \varnothing 16$ & $4 \varnothing 16$ & $4 \varnothing 16$ & \\
\hline \multirow[t]{2}{*}{ B5 } & $400 \times 400$ & Top & $8 \varnothing 16$ & $5 \varnothing 16$ & $8 \varnothing 16$ & \\
\hline & & Bottom & $5 \varnothing 16$ & $5 \varnothing 16$ & $5 \varnothing 16$ & \\
\hline \multirow[t]{2}{*}{ B6 } & $200 \times 400$ & Top & $3 \varnothing 16$ & $3 \varnothing 16$ & $3 \varnothing 16$ & \\
\hline & & Bottom & $3 \varnothing 16$ & $3 \varnothing 16$ & $3 \varnothing 16$ & \\
\hline \multirow[t]{2}{*}{ CB } & $400 \times 400$ & Top & $\begin{array}{c}10 \varnothing \\
16 \\
\end{array}$ & $\begin{array}{c}10 \varnothing \\
16 \\
\end{array}$ & $\begin{array}{c}10 \varnothing \\
16 \\
\end{array}$ & \\
\hline & & Bottom & $6 \varnothing 16$ & $6 \varnothing 16$ & $6 \varnothing 16$ & \\
\hline
\end{tabular}

Table (5.0): Section properties of RC columns of building Model-06

\begin{tabular}{|c|c|c|c|c|}
\hline Story & Columns & $\begin{array}{l}\text { Dimension } \\
(\mathrm{mm})\end{array}$ & reinforcement & Ties \\
\hline \multirow[t]{3}{*}{ Basement } & $\overline{C 1}$ & $400 \times 600$ & $8 \varnothing 25$ & \multirow{12}{*}{$\begin{array}{c}\varnothing 12 @ 0 \\
200 \\
\mathrm{~mm}\end{array}$} \\
\hline & $\mathrm{C} 2$ & $400 \times 600$ & $8 \varnothing 25$ & \\
\hline & $\mathrm{C} 3$ & $400 \times 600$ & $12 \varnothing 20$ & \\
\hline \multirow[t]{3}{*}{ Ground Story } & $\mathrm{C} 1$ & $400 \times 600$ & $8 \varnothing 25$ & \\
\hline & $\mathrm{C} 2$ & $400 \times 500$ & $8 \varnothing 25$ & \\
\hline & C3 & $400 \times 500$ & $12 \varnothing 16$ & \\
\hline \multirow[t]{3}{*}{ Story 1} & $\mathrm{C} 1$ & $400 \times 500$ & $8 \varnothing 25$ & \\
\hline & $\mathrm{C} 2$ & $400 \times 450$ & $8 \varnothing 25$ & \\
\hline & $\mathrm{C} 3$ & $400 \times 450$ & $12 \varnothing 16$ & \\
\hline \multirow[t]{3}{*}{$\begin{array}{c}\text { Story } 2,3,4,5 \\
\text { and story } 6\end{array}$} & $\mathrm{C1}$ & $400 \times 500$ & $\begin{array}{c}4 \varnothing 20 \& 4 \varnothing \\
16\end{array}$ & \\
\hline & $\mathrm{C} 2$ & $400 \times 400$ & $8 \varnothing 25$ & \\
\hline & C3 & $400 \times 400$ & $8 \varnothing 16$ & \\
\hline
\end{tabular}

abdi.abdi@uod.ac 

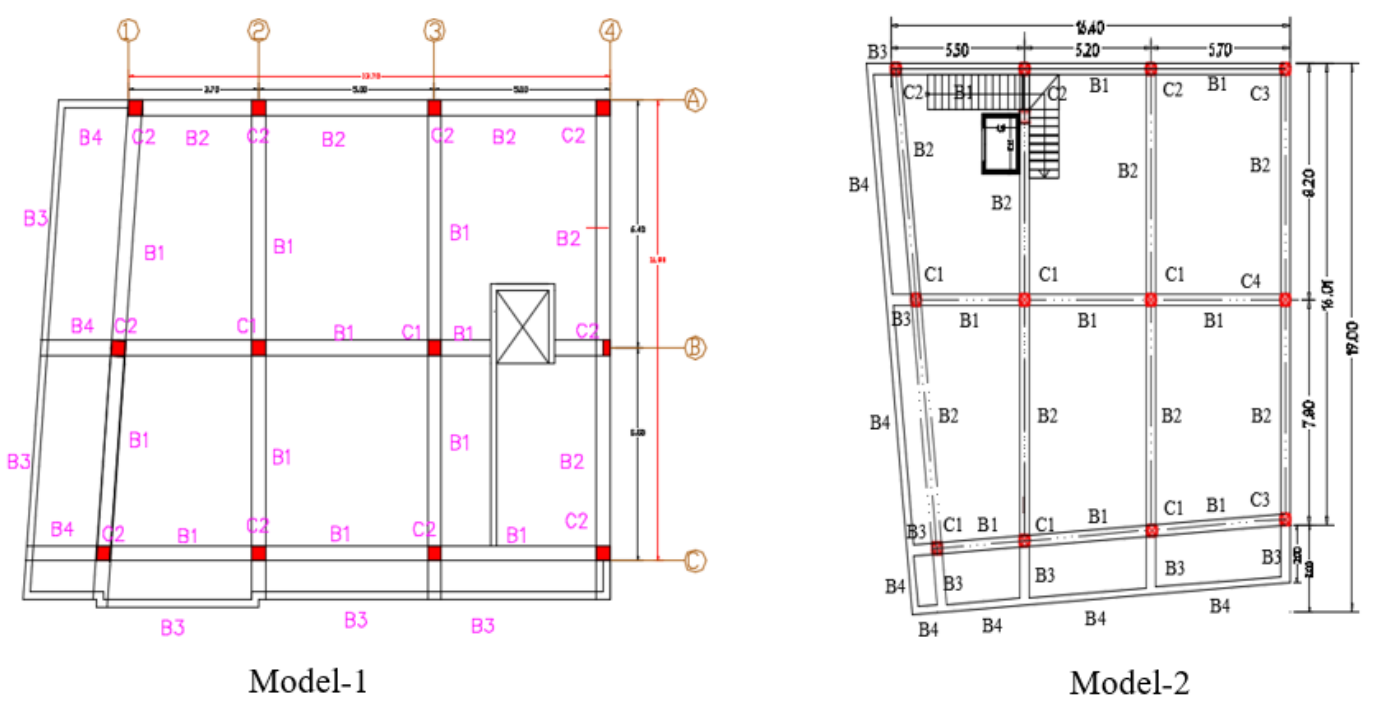

Fig. (6.0): Typical structural floor plan of building model-1 and model-2

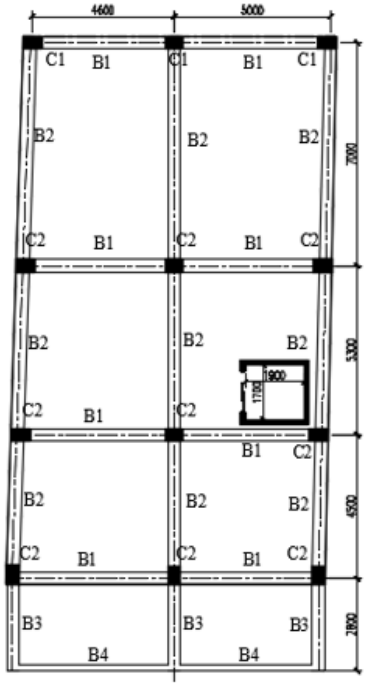

Model-3

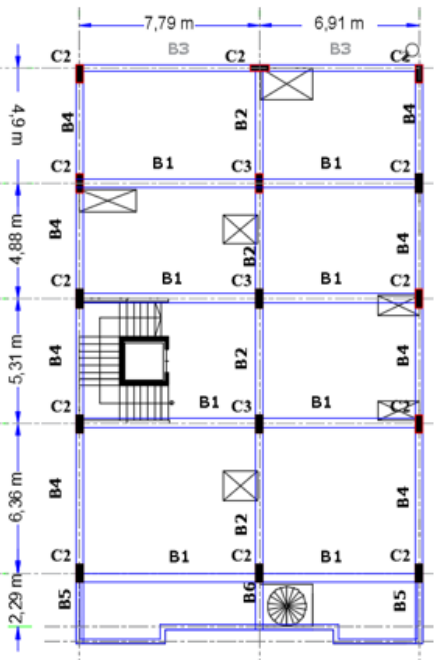

Model-4

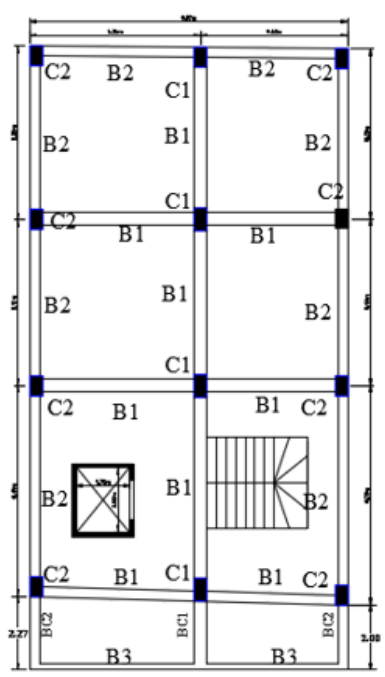

Model-5

Fig. (7.0): Typical structural floor plan of building model-3, model-4 and model-5

\subsection{Modeling of representative buildings}

The buildings are modeled as threedimensional bare frames in ETABS software which are consist of beams, columns, slabs, and walls. Generally, the modeling of buildings was based on the properties obtained from original drawings in terms of element dimensions, span lengths, reinforcement details, and design gravity loads. Beams and columns are modeled as frame elements using the material properties, crosssectional dimensions and rebar details specified for each building. The shell elements such as slabs and walls are modeled based on the available information in the design original drawings with assigning rigid diaphragm for the slabs. Shear walls of the basement and elevators are also modeled by the section designer to provide thickness and reinforcement details. In addition, the auto mesh with element size $500 \mathrm{~mm}$ is assigned for slabs and walls. The 3D model of representative building model-6 is presented in (Fig. 8.0) which its properties have been described previously.

The material properties consist of compressive strength of concrete and yield strength of reinforcement which are obtained from original design drawings. The modulus of elasticity of concrete $(\mathrm{Ec})$ is obtained by $4700 \sqrt{f_{c}^{\prime}}$ (Mpa) relation (where; $f_{c}^{\prime}$ is the designed compressive strength of concrete) and modulus of elasticity for reinforcement (Es) provided approximately to 200,000 Mpa, these values are according to (ACI- 
318 , 2011). Furthermore, in the nonlinear data definition of materials in ETABS software, the mander stress-strain model and simple stressstrain curve were selected for concrete and steel reinforcement, respectively.

The material nonlinearity of structural elements is modeled by lumped plasticity philosophy which concentrates plasticity of the member at discrete points called plastic hinges. The generalized nonlinear load-deformation curve of the hinge property presented in (Fig. 8.0) as defined by FEMA 356. The curve shows the linear response from $\mathrm{A}$ to yield at $\mathrm{B}$, then reduced stiffness from $\mathrm{B}$ to ultimate strength at $\mathrm{C}$ and sudden reduction in lateral load resistance to $\mathrm{D}$ then response at reduced resistance to $\mathrm{E}$. The points IO, LS, and $\mathrm{CP}$ stand for immediate occupancy, life safety, and collapse prevention respectively. In this study, automatically generated plastic hinges are used in ETABS based on the section properties, material, reinforcement and length of the elements according to ASCE 41-

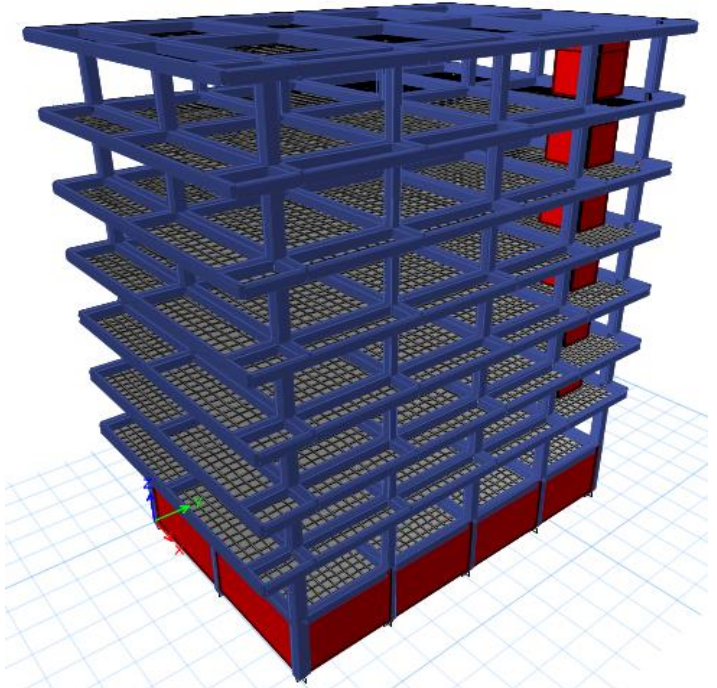

17 tabulated values (Computer \& Structures Inc., 2018). Three types of plastic hinges assigned to structural members including; uncoupled moment (M3) hinges to RC beams in flexure, Coupled (PM2-M3) hinges to RC columns in axial force with bi-axial bending moments, and Coupled fiber hinges (P-M3) assigned to RC shear walls. The plastic hinges are assigned to the ends of beams and columns with relative distances of 0.1 and 0.9 of element lengths. Whereas, for walls, they are assigned to the center of elements.

The mass source has been defined in ETABS for all building models as recommended by FEMA 356. In this study, the mass source is defined as full dead load plus $25 \%$ of the live load if live load less than or equal to $3 \mathrm{kN} / \mathrm{m}^{2}$, and $50 \%$ if live load above $3 \mathrm{kN} / \mathrm{m}^{2}$. Additionally, the geometric nonlinearity (P-Delta) effect was considered in the analysis. The load combination utilized for this purpose was (1.0 dead+0.5 live) loads.

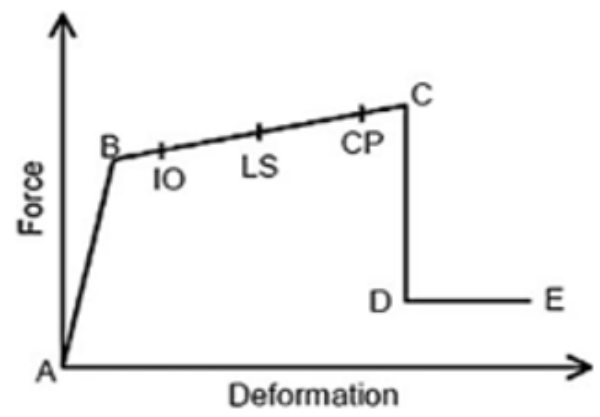

Fig. (8.0): (Right) Nonlinear load-deformation of component (hinge property), (Left) Three dimensional finite element based model of representative building model- 6

\section{RESULTS AND DISCUSSION}

The displacement control pushover analysis has been employed for the building models in ETABS software in $\mathrm{X}$ and $\mathrm{Y}$ directions. In the pushover load cases, the uniform acceleration is defined in both directions as a load type for the analysis with considering the effect of geometric nonlinearity (P-Delta). While, the effect of pounding, infills and soil structure interaction was out of study scope. The seismic performance of each building model is evaluated by using the improved capacity spectrum method according to
FEMA 440 (ATC-55, 2005). The building models are subjected to response spectrum seismic hazard of Duhok city in terms of spectral response accelerations $\mathrm{Ss}$ and $\mathrm{S}_{1}$ as $0.6 \mathrm{~g}$ and $0.2 \mathrm{~g}$ respectively, for a $2 \%$ chance of exceedance in 50 years or return period of 2475 years. Also, the site soil class is considered as D (stiff soil) for all selected buildings in the city.

The performance points of building models which is the intersection between capacity spectrum (green) and single demand spectrum (red) curves are presented in (Fig. 9.0). 
In addition, the seismic responses of buildings at their performance points are provided in Table 6.0 in terms of base shear, roof displacement, spectral acceleration and effective period. As well, the other characteristics of buildings such as effective damping and ductility ratios are presented.

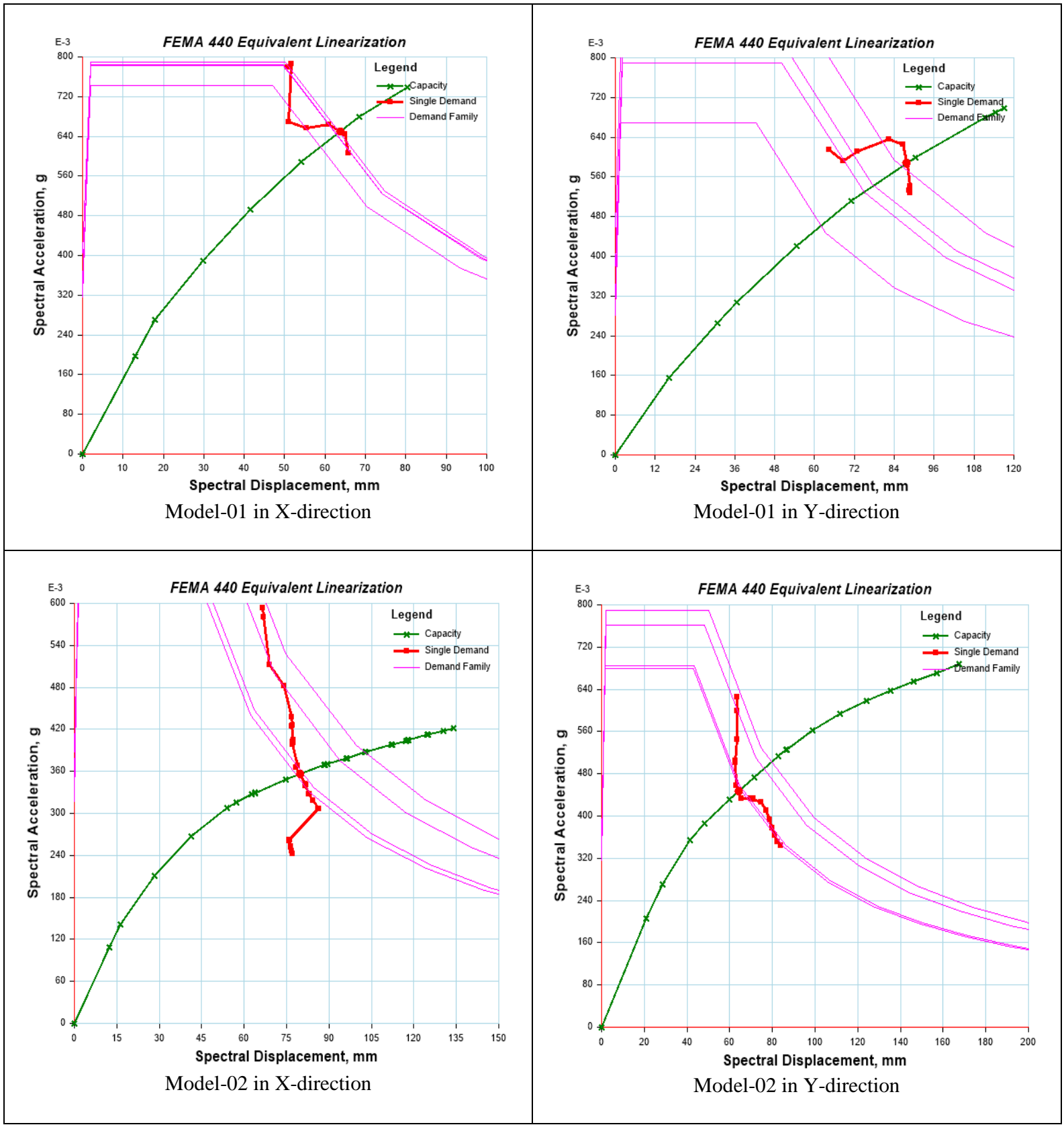




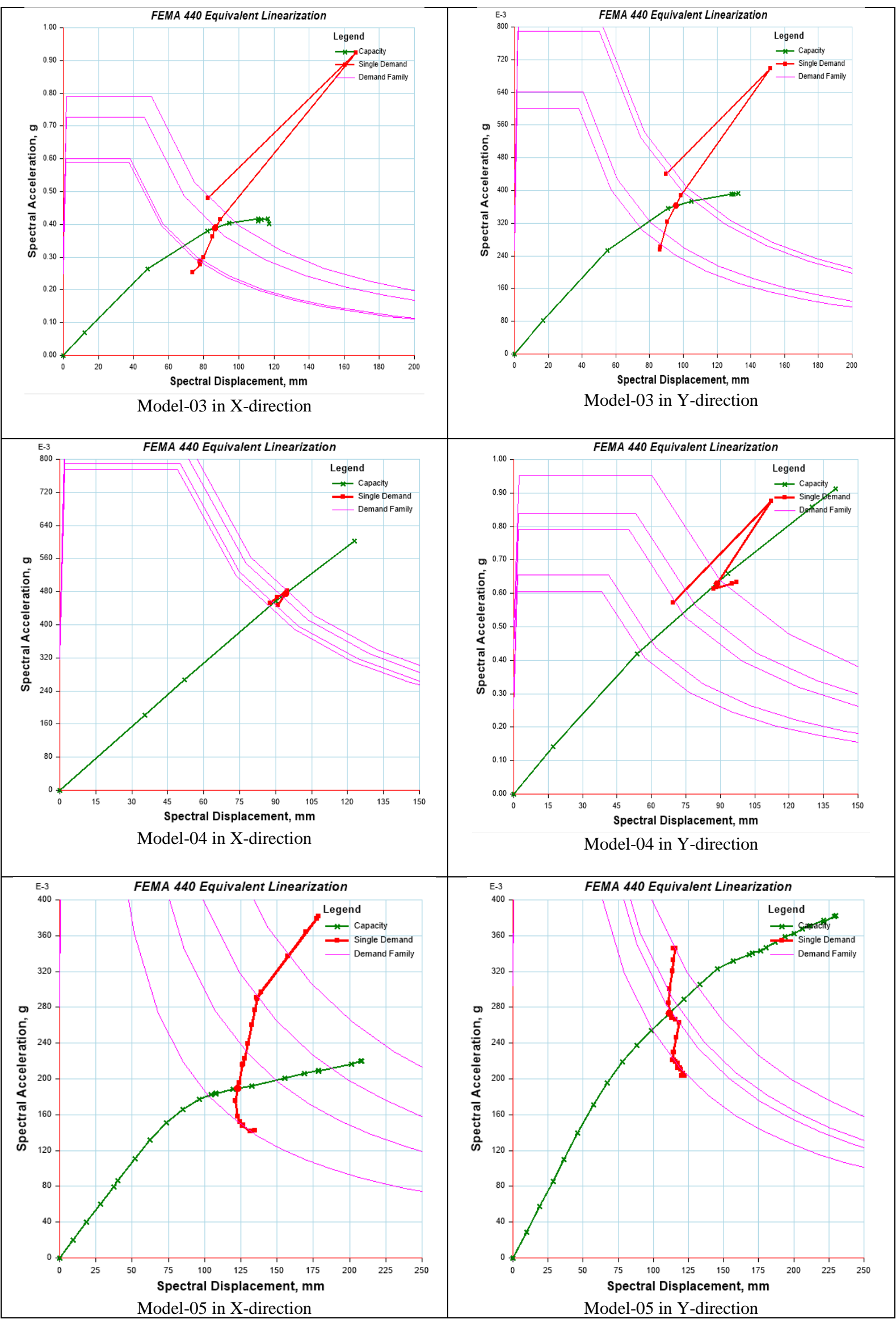

abdi.abdi@uod.ac 


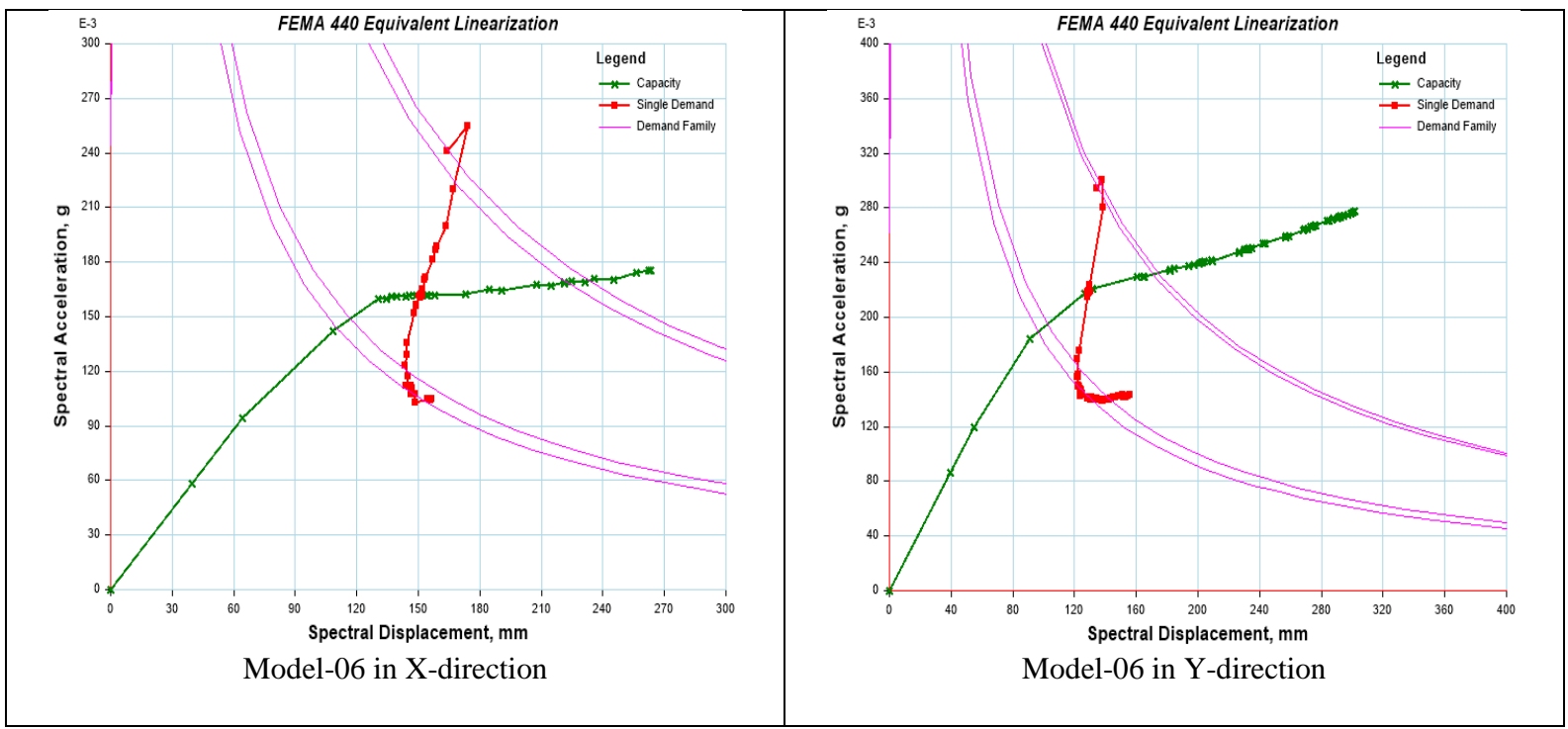

Fig. (9.0): Performance points of building models

Table (6.0): Seismic responses of building models at performance points

\begin{tabular}{|c|c|c|c|c|c|c|c|}
\hline $\begin{array}{l}\text { Model } \\
\text { No. }\end{array}$ & $\begin{array}{l}\text { Direction } \\
\text { of push }\end{array}$ & $\begin{array}{c}\text { Displaceme } \\
\mathrm{nt} \\
\mathrm{mm} \\
\end{array}$ & $\begin{array}{c}\text { Base shear } \\
\text { kN }\end{array}$ & $\begin{array}{c}\text { Spectral } \\
\text { acceleration g }\end{array}$ & $\begin{array}{l}\text { Effective period } \\
\text { sec }\end{array}$ & $\begin{array}{c}\text { Effective } \\
\text { damping \% }\end{array}$ & $\begin{array}{c}\text { Ductility } \\
\text { ratio }\end{array}$ \\
\hline \multirow[t]{2}{*}{1} & $\bar{x}$ & 78.05 & 4840.79 & 0.65 & 0.745 & 14.9 & 2.87 \\
\hline & $\bar{Y}$ & 84.93 & 4782.7 & 0.588 & 0.987 & 16.2 & 3.07 \\
\hline \multirow[t]{2}{*}{2} & $\bar{X}$ & 98.75 & 5481.35 & 0.35 & 1.046 & 16.8 & 3.18 \\
\hline & $\bar{Y}$ & 90.96 & 6069.62 & 0.44 & 0.767 & 9.6 & 2.12 \\
\hline \multirow[t]{2}{*}{3} & $\bar{X}$ & 120 & 4786.0 & 0.389 & 0.99 & 9.5 & 2.1 \\
\hline & $\bar{Y}$ & 123.83 & 4501.6 & 0.362 & 1.095 & 9.8 & 2.15 \\
\hline \multirow[t]{2}{*}{4} & $\bar{X}$ & 133.23 & 12121.89 & 0.47 & 0.967 & 7.2 & 1.74 \\
\hline & $\mathrm{Y}$ & 121.76 & 16617.63 & 0.629 & 0.945 & 12.9 & 2.58 \\
\hline \multirow[t]{2}{*}{5} & $\bar{X}$ & 187.31 & 2869.19 & 0.189 & 1.47 & 6.7 & 1.64 \\
\hline & $\bar{Y}$ & 172.42 & 4365.07 & 0.273 & 1.258 & 7.1 & 1.72 \\
\hline \multirow[t]{2}{*}{6} & $\bar{x}$ & 182.8 & 4018.17 & 0.161 & 1.79 & 6.9 & 1.68 \\
\hline & $\bar{Y}$ & 159.41 & 5304.51 & 0.219 & 1.48 & 7.2 & 1.73 \\
\hline
\end{tabular}

The performance points for the building models have been determined as previously presented. They represent the maximum expected seismic demands of the buildings under specified earthquake action.

From the performance point figures of building models 1,2 in $\mathrm{X}$ dir., 3 , and 4 , it is obvious that the capacity spectrum has intersected the demand spectrum curve near the final steps or inelastic region. This indicates that these buildings have poorly behaved during specified earthquake action and the margin of safety against collapse is low because a sufficient amount of deformation and strength are not reserved. From Table 6.0, it is noted that the effective period of the buildings increased with the increase in the number of stories (increasing in mass).

The ductility ratio is the ratio of ultimate displacement of building to the displacement at yielding or first damage. The bigger ductility ratio makes the building undergo larger displacement beyond elastic limit without stiffness and strength loss significantly. It works as an energy dissipater (shock absorber) as well. This is clearly noted in Table 6.0 since the effective damping increased with the increasing of ductility ratio. 
The lateral deformation of buildings in terms of maximum inter-story drift ratio at performance points shown in (Fig. 10) in X and Y directions.

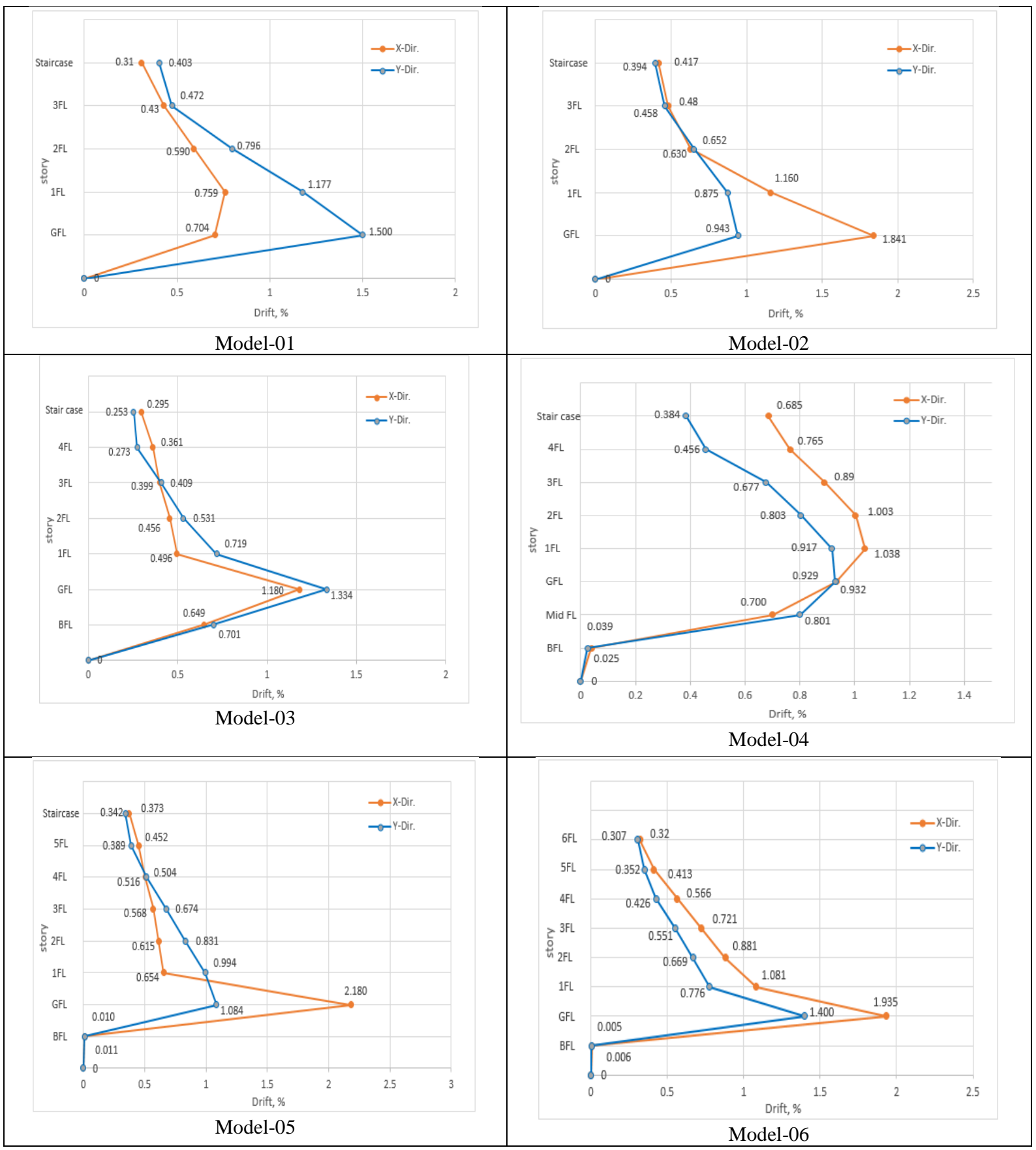

Fig. (10): Maximum inter-story drift ratio at performance points of the building models

Based on the maximum inter-story drift ratios of the building models at performance points, it can be seen that the ground story is the most vulnerable story within the building. In which the larger inter-story drift accumulated than upper stories due to inadequate lateral stiffness in one or both directions.
The global performance level of the buildings can be assessed from the lateral deformation compared to the acceptable limits provided in Table 1.0. The maximum inter-story drift ratios of all building models except model-5 in X dir. are between $1.0 \%$ and $2.0 \%$, which indicates that the buildings are between IO and LS performance 
levels known as damage control range. According to descriptions of FEMA 356 and ATC 40, the building in this range has limited structural damages with minimized repair time. In contrast, the inter-story drift of model-5 in X dir. is $2.18 \%$ at the ground story which can be categorized in (LS-CP) performance level. While it is less than the structural stability $(\mathrm{CP}) \operatorname{limit}\left(0.33 \frac{V_{i}}{P_{i}}=5 \%\right)$. This means that the building in $\mathrm{X}$ direction lies between LS and CP levels called limited safety range. Based on the aforesaid guidelines descriptions, moderate structural damage occur in the building model-5 in $\mathrm{X}$ dir. with some permanent drift and damage to partitions. However, the building is stable to carry the gravity loads without a partial or total collapse of structural members.

The deformed shapes and developed plastic hinges of the building models at the performance points are presented in (Fig.11). The figures of plastic hinges are presented in terms of limits of plastic hinge status (IO, LS, and CP) which are represented by colors. Moreover, the number of plastic hinges (hinge states) between discrete points (A, B, C, D, and E) of the load-deformation curve of the elements of the buildings are illustrated in Table 7.0.

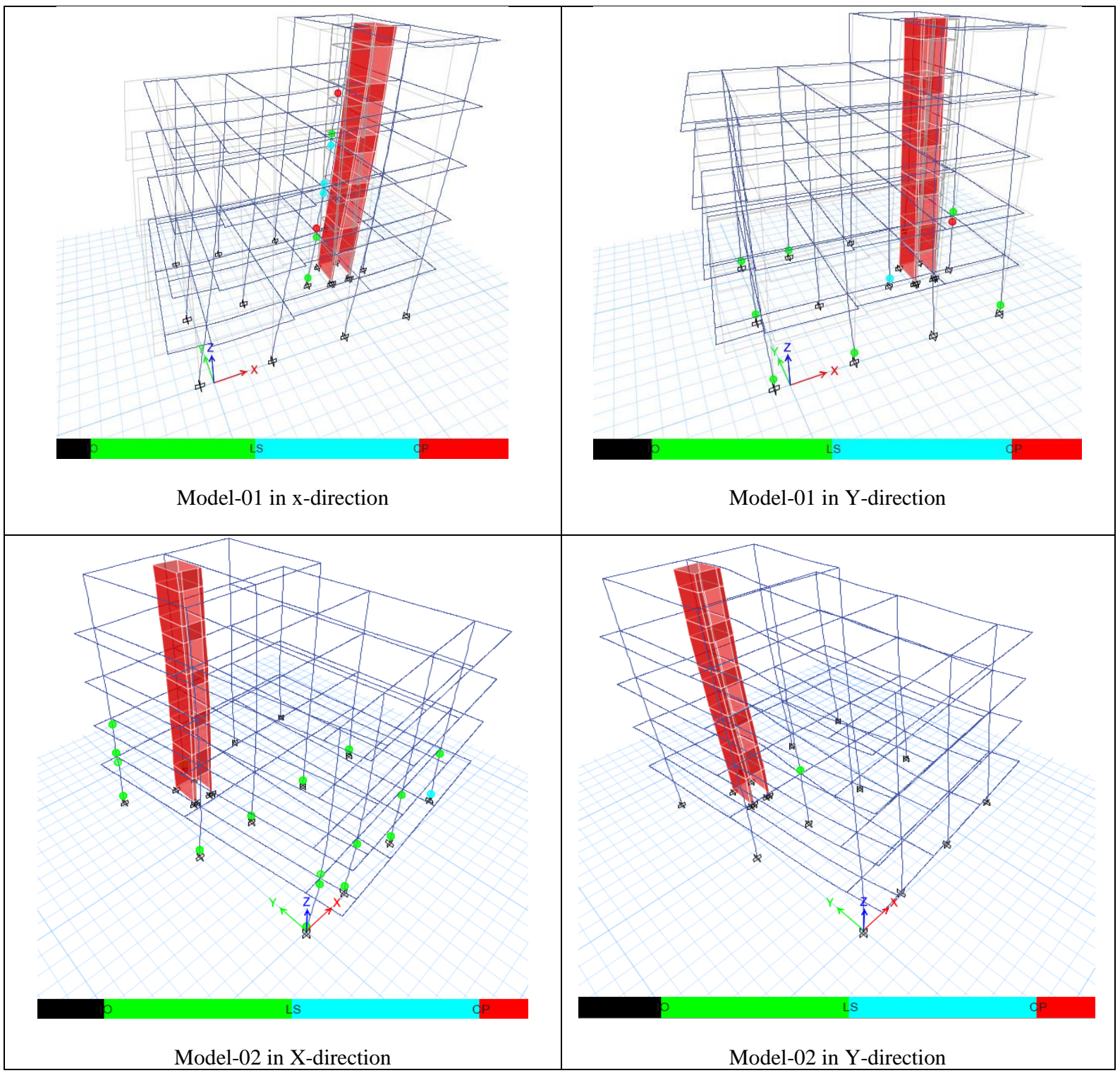




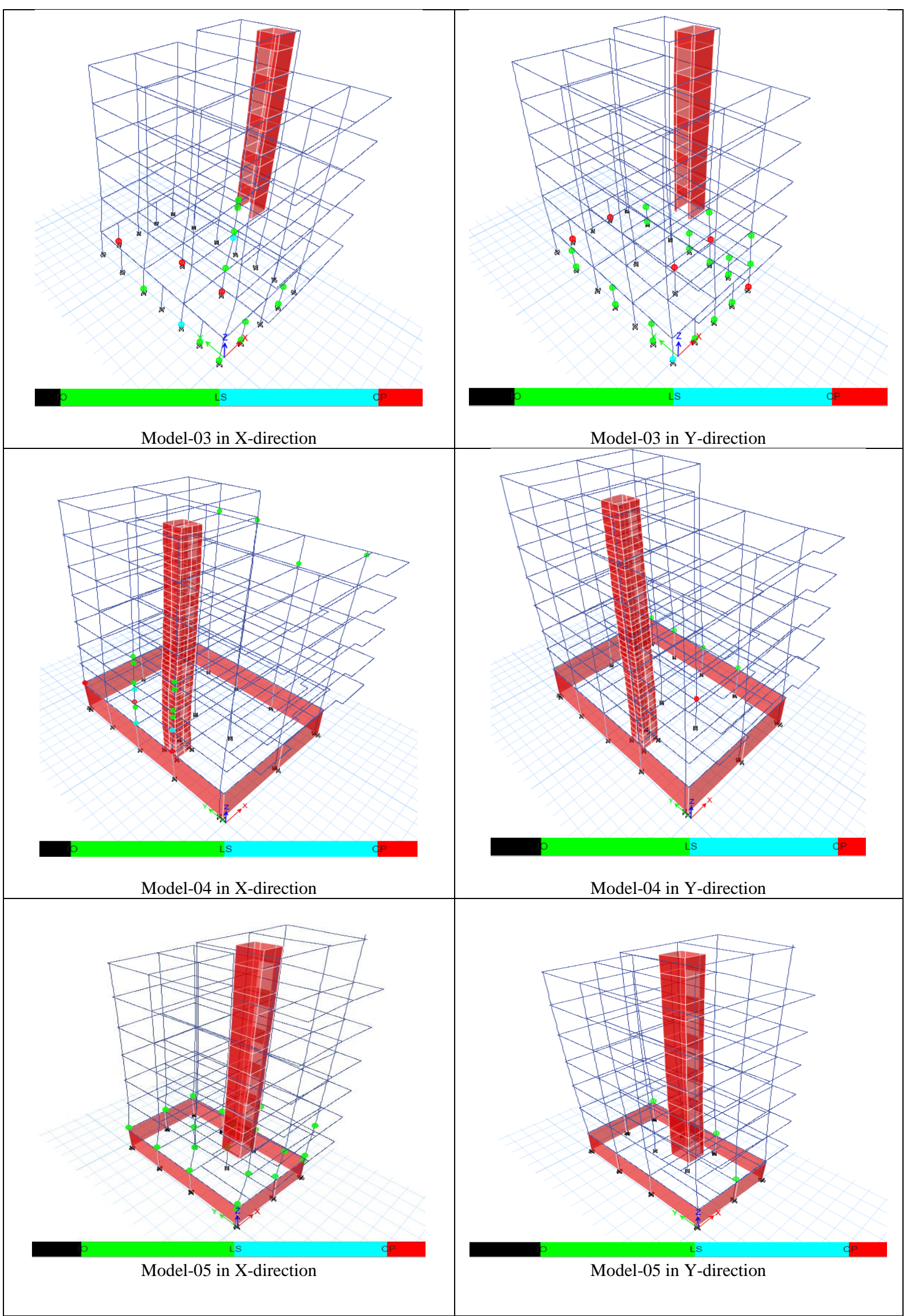




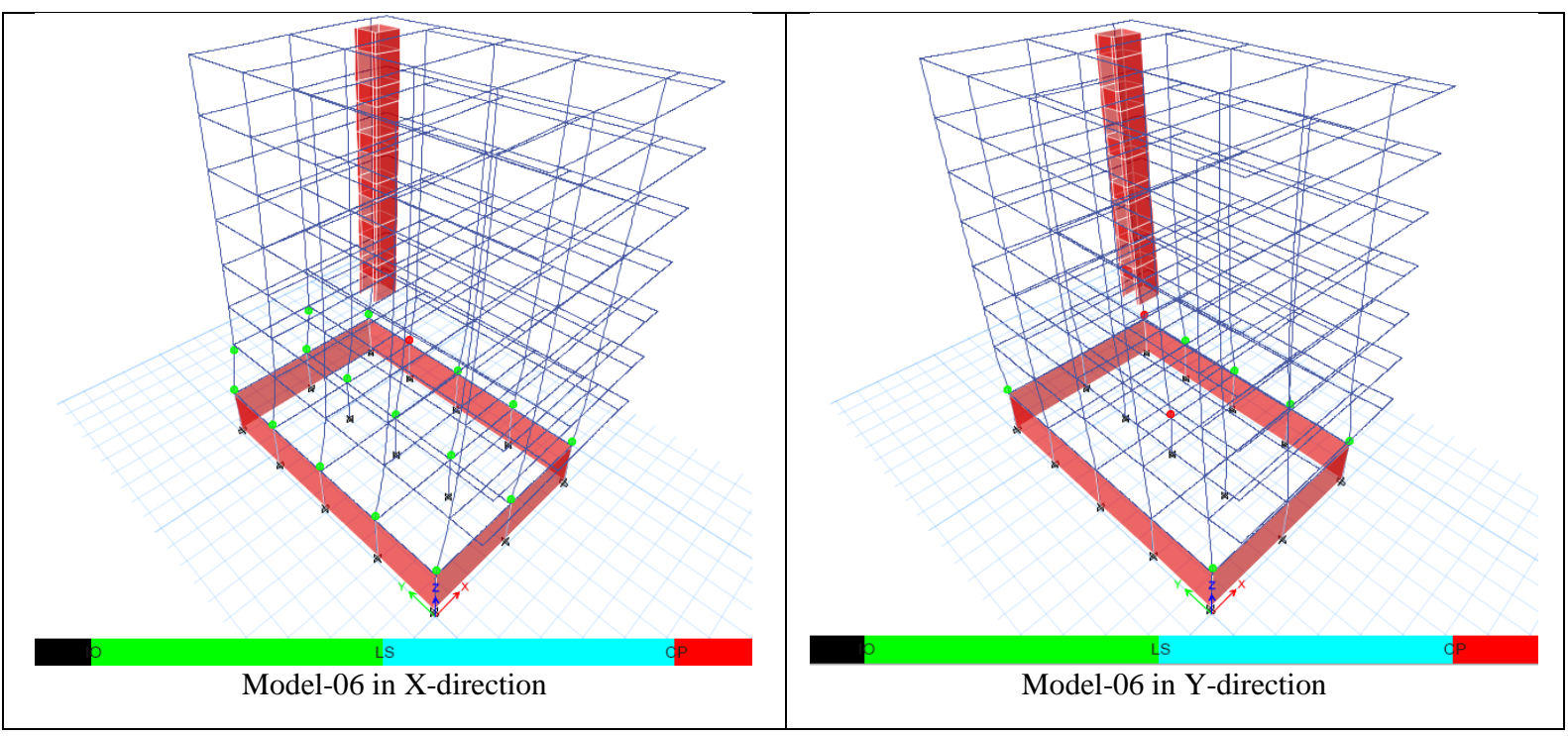

Fig. (11.0): Developed plastic hinges of building models at performance points

Table (7.0): Plastic hinge states at performance point of buildings

\begin{tabular}{|c|c|c|c|c|c|c|c|c|c|}
\hline $\begin{array}{l}\text { Model } \\
\text { No. }\end{array}$ & $\begin{array}{l}\text { Direction } \\
\text { of push }\end{array}$ & $\begin{array}{l}\text { Total } \\
\text { steps }\end{array}$ & $\begin{array}{l}\text { Performance } \\
\text { point step }\end{array}$ & A-B & B-C & C-D & D-E & $>E$ & Total \\
\hline \multirow[t]{2}{*}{1} & $\bar{X}$ & 7 & 6 & 768 & 75 & 0 & 0 & 0 & 843 \\
\hline & $\bar{Y}$ & 11 & 6 & 755 & 88 & 0 & 0 & 0 & \\
\hline \multirow[t]{2}{*}{2} & $\mathrm{X}$ & 31 & 14 & 558 & 237 & 0 & 0 & 0 & 795 \\
\hline & $\bar{Y}$ & 19 & 7 & 689 & 106 & 0 & 0 & 0 & \\
\hline \multirow[t]{2}{*}{3} & $\bar{X}$ & 12 & 5 & 739 & 224 & 0 & 0 & 0 & 963 \\
\hline & $\bar{Y}$ & 8 & 4 & 761 & 200 & 0 & 2 & 0 & \\
\hline \multirow[t]{2}{*}{4} & $\bar{X}$ & 4 & 4 & 1166 & 169 & 0 & 0 & 1 & 1336 \\
\hline & $\bar{Y}$ & 5 & 3 & 1050 & 286 & 0 & 0 & 0 & \\
\hline \multirow[t]{2}{*}{5} & $\bar{X}$ & 28 & 15 & 942 & 130 & 0 & 0 & 0 & 1072 \\
\hline & $\bar{Y}$ & 29 & 12 & 900 & 172 & 0 & 0 & 0 & \\
\hline \multirow[t]{2}{*}{6} & $\mathrm{X}$ & 29 & 12 & 1604 & 78 & 0 & 0 & 0 & 1682 \\
\hline & $\bar{Y}$ & 48 & 5 & 1542 & 140 & 0 & 0 & 0 & \\
\hline
\end{tabular}

During the nonlinear static analysis, the plastic hinges are started to develop at every deformation step in the structural members. It has been observed that in more than $80 \%$ of the selected buildings, hinges are formed in the columns prior to beams or together especially in the ground story, then propagated to upper stories with yielding of interior beams and columns. This indicates that most of the buildings do not satisfy the strong column-weak beam criteria. The same problem has been observed in the RC buildings in Erbil city according to the study conducted by (Abduljaleel, Taha and Yaseen, 2020). It means that the buildings in KR in general and Duhok city in particular, have been designed by old conventional design approaches rather than performance-based design methods.

Based on the developed plastic hinge figures, in models 1, 3, 4, and 6 several columns passed the CP limit, especially at the ground stories. While models 2 and 5 remain between LS-CP and IO-LS respectively. The local (component) performance of the buildings can be assessed according to the descriptions of FEMA 356. Damage with spalling of concrete cover and shear cracking (crack width < 1/8") will occur in the columns in LS performance level which most of the columns in the buildings have this level as presented in figures. For the columns that reached $\mathrm{CP}$ and more, extensive cracking, splice failure in 
non-ductile columns and severe damage in short columns will occur.

Even though, the global performance indicated that limited damage will occur in most of the buildings. But the local performance of components revealed that the columns in most of the buildings will experience extensive cracking, especially at ground stories. It means that the extensive damage in columns will have an effect on the stability of the buildings during earthquakes. Besides, several other factors have significant effects on the damage extent of the buildings during an earthquake, which are not considered in this study such as; pounding, horizontal and vertical irregularity, soil structure interaction, and effect of infill walls. Also, the design deficiencies and carelessness to the reinforcement details especially at beam-column connections are other factors that are expected to amplify the damage level. Therefore, the columns of the ground story in all selected buildings need to be strengthened.

\section{CONCLUSION}

This study has been carried out to assess the seismic vulnerability of the existing $\mathrm{RC}$ buildings in Duhok city. Six RC buildings with different number of stories were selected for nonlinear static analysis. It has been known that the nonlinear static (pushover) analysis is a simple method to evaluate the nonlinear seismic response of the buildings. From the analysis results the following points can be concluded:

1. The buildings have been designed according to old conventional design approaches rather than performance-based design method. Therefore most of the buildings behaved like weak columnstrong beam system. So this type of buildings will have poor behavior during earthquakes with little deformation and strength reservation.

2 . The overall damage of the buildings is limited, while, the buildings experience some damages in the columns in general and ground stories in particular without a partial or total collapse of buildings.

3. The buildings have suffered damages at the ground stories rather than upper stories due to the inadequate lateral stiffness of the buildings at that story. This damage increases the probability of soft-story failure. Thus the columns at ground stories are required to be strengthened.

4. The results proved the careless supervision of the meant authorities on the design and construction process of the buildings. In addition, they revealed that the deficiencies of building designs are either due to missing the Kurdistan region seismic design code or less attention paid to applying the available seismic codes in the designing of buildings. So, local authorities need to legislate new rules and regulations regarding the seismic design and execution of the new buildings based on the seismicity of the city and updated available seismic codes. Furthermore, the reinforcement details must be applied correctly during the construction process especially the details of beam-column connection at which the damages are likely to occur during an earthquake.

\section{REFERENCES}

Abduljaleel, Z. A., Taha, B. O. and Yaseen, A. A. (2020) "Seismic Vulnerability Assessment of Reinforced Concrete Building Structures in Erbil City, Capital City of Kurdistan Region of Iraq," Eurasian Journal of Science \& Engineering, 6(1), pp. 161-182.

Abdulnaby, W. et al. (2014) "Seismotectonics of the Bitlis-Zagros Fold and Thrust Belt in Northern Iraq and Surrounding Regions from Moment Tensor Analysis," Pure and Applied Geophysics, 171(7), pp. 1237-1250.

ACI-318 (2011) "Building Code Requirements for Structural Concrete (ACI 318-11)," in American Concrete Institute.

Ahmed, S. Y. (2013) "Seismic Evaluation of Reinforced Concrete Frames Using Pushover Analysis," Al-Rafidain Engineering, 21(3), pp. 28-45.

Al-jassim, S. A. B. J. and Husssain, M. A. (2018) "Pushover Analysis of $\mathrm{G}+5$ Reinforced Concrete Building in Basrah," International Journal of Innovations in Engineering and Technology, 11(1), pp. 53-59.

Al-shijbi, Y. et al. (2019) "Probabilistic seismic hazard assessment for the arabian peninsula," Pure and Applied Geophysics, 176(4), pp. 15031530.

Alsinawi, S. a and Al-qasrani, Z. O. (2003) "Earthquake Hazards Considerations for Iraq," Fourth International Conference of Earthquake Engineering and Seismology, (May), pp. 0-8.

Ameer, A. S. et al. (2005) "Probabilistic seismic hazard assessment for Iraq using complete earthquake catalogue files," Pure and Applied Geophysics, 162(5), pp. 951-966.

Amer, A.-N., Sobaih, M. and Adel, A. (2016) "Investigation of Effects of Capacity Spectrum Method on Performance Evaluation of MultiStory Buildings According to the IRAQI Seismic Code Requirements," Open Journal of Civil Engineering, 6(6), pp. 420-441.

ASCE (2000) Prestandard and Commentary for the Seismic Rehabilitation of Buildings, FEMA 
356. Washington, D.C.

ATC-55 (2005) "Improvement of Nonlinear Static Seismic Analysis Procedures," FEMA 440, Federal Emergency Management Agency, Washington $D C$.

ATC 40 (1996) "Seismic evolution and retrofit of concrete buildings."

Boen, T. and Tjhin, T. N. (2016) "MDOF Effects on the Accuracy of Nonlinear Static Seismic ( Pushover ) Procedures," ResearchGate, pp. 119.

Chen, W.-F. and Lui, E. M. (2006) Earthquake engineering for structural design. Boca Raton: CRC Press Taylor\&Francis Group.

Computer \& Structures Inc. (2018) "CSI Analysis Reference Manual." United States of America: CSI.

Datta, T. K. (2010) Seismic analysis of structures. John Wiley \& Sons (Asia) Pte Ltd.

Elnashai, A. S. and Di Sarno, L. (2015) Fundamentals of earthquake engineering From source to Fragility. 2nd ed. Southern Gate: John Wiley \& Sons, Ltd.

Freeman, S. A. (1998) "the capacity spectrum method for determining the demand displacement." Emeryville: Wiss, Janney, Elstner Associates, Inc.

Freeman, S. A. (2004) "Review of the development of the capacity spectrum method," ISET Journal of Earthquake Technology, 41(438), pp. 1-13.

Hosseini, R. et al. (2014) "Proposed Seismotectonic Provinces for Kurdistan Region - NorthEastern," International Journal of Current Life Sciences, 4(11), pp. 9060-9066.

Krawinkler, H. (1998) "Pros and cons of a pushover analysis of seismic performance evaluation,"
Enfineering Structures, 20(4-6), pp. 452-464.

Lagaros, N. D., Mitropoulou, C. C. and Papadrakakis, M. (2014) "Time history seismic analysis," Encyclopedia of Earthquake Engineering, (June 2015). doi: 10.1007/978-3-642-36197-5.

Ministry of housing and construction (2017) Iraqi Seismic Blog. Iraq.

Oguz, S. (2005) Evaluation of pushover analysis procedures for frame structures. Middle East Technical University.

Pinho, R. (2007) "Advanced Earthquake Engineering Analysis," Advanced Earthquake Engineering Analysis, (January). doi: 10.1007/978-3-21174214-3.

Sa'ad Al-Deen, Q. and Abdulrasool, M. A. (2017) "Database of dynamic soil properties for most Iraq soils," American Scientific Research Journal for Engineering, Technology, and Sciences (ASRJETS), pp. 230-254.

Said, A. M. I. and Farman, M. S. (2018) "Reevaluations of seismic hazard of Iraq," Arabian Journal of Geosciences. Arabian Journal of Geosciences, 11(11).

Wang, Y. J. et al. (2016) "Probabilistic seismic hazard assessment for iraq," Terrestrial, Atmospheric and Oceanic Sciences, 27(3), pp. 325-340. doi: 10.3319/TAO.2016.05.03.01(TEM).

Yaseen, A. A., Begg, D. and Nanos, N. (2014) "Time history analysis of existing buildings in the kurdistan region of Iraq," in First International Engineering Conference (IEC2014).

Zare, M. et al. (2017) "Preliminary report of Mw7. 3 Sarpol-e Zahab, Iran earthquake on November 12, 2017," EMSC Report, 2017(Fig 4), pp. 110 . 